\title{
Border Tourism on the Russian-Chinese Border
}

\author{
Ekaterina V. Mikhailova* \\ Higher School of Economics \\ 20 Miasnitskaia, Moscow, 101000, Russia
}

Received 27.07.2014, received in revised form 29.12.2014, accepted 14.01.2015

The paper focuses on the tourism development strategy of the Amur Oblast called "Twin Cities". Said initiative became the first attempt of the Russian Far Eastern regions to create the hospitality industry towards Chinese tourists in the Sino-Russian borderlands. Bringing together such sub-disciplines as border tourism, urban planning and territorial development helps to find out the peculiarities of Blagoveshchensk and Heihe relations among other adjacent settlements along the Russian-Chinese border. Detected features give the ground to define "twin-cities" rhetoric around the border city pair under the scrutiny as a touristic brand construction. On the basis on Blagoveshchensk and Heihe investment plans analysis, the author argues that studied initiative might reshape unbalanced onesided structure of current tourist flow across the Russian-Chinese border.

Keywords: border tourism, trans-border agglomeration, twin-cities, border cities, russian-chinese borderland.

Research area: economics.

\section{Introduction}

Nowadays the transborder tourist flow in the Russian-Chinese borderlands is mainly onesided - Russians are visiting Chinese border cities to buy goods and services enjoying visafree regime there. At the same time, with increasing frequency Russian border regions tend to name tourism industry as a potential tool for diversification of their regional economy (for instance see Government of Amur oblast, 2011).

Taking into account increasing level of life among certain groups of Chinese society (Guo, Kim and Timothy, 2007, p. 329) and enhancing demand for outbound international tourism among Mainland China's residents (ibid, p. 315), the author examines the idea of attracting Chinese visitors to cross the border to Blagoveshchensk using "twin-cities" as a touristic brand.

For years border regions of the Russian Far East were dominated with the misleading rhetoric of "Chinese demographic expansion" (Prosvirnov, 2009, p. 62) and "yellow threat" (Ioffe and Ryzhova, 2009, p. 351). As a result Russian border policy in the Eastern direction mostly was aimed to limit informal economic practices and eradicate illegal migration. Current initiative of the Amur oblast Government represents the first attempt to create the hospitality industry towards Chinese tourists with the ambition later on to gain the permanently increasing incoming international tourist flow.

(C) Siberian Federal University. All rights reserved

* Corresponding author E-mail address: mikhaylovaev@yandex.ru 


\section{Research Context}

Thanks to the rapid development of border tourism studies, the assumption that borders have a dynamic influence on tourism has reached the level of the universal truth. As Gelbman stated, both political boundaries, governmental policies, administrative management of the border on both sides and physical barriers that borders create (2010, p. 84) affect tourism. The places that experience impact of all above-mentioned externalities in the first instance include the immediate borderland.

Contiguous settlements divided with the state border have deserved the reputation of being "laboratories" (Anishchenko and Sergunin, 2012, p. 28) for testing projects and strategies, rules and norms that later might be extrapolated to the whole region, country or group of countries. The practice of compartmentalization of analysis of various social phenomena with focusing on such adjoining towns inspired the author to view the border tourism through a microscope - at the smallest of available scales. Thus, the paired border settlements calling themselves "twin cities" were chosen as a research unit to observe the complexity of twisted processes that influence border tourism in the concise way.

From a theoretical point of view, the term "twin-cities" is a disputable concept with no agreed definition in academic literature (Anishchenko and Sergunin, 2012, p. 28). It describes relations between contiguous settlements divided with a border (in our case - an outer state border). Some scholars suppose that applying the term "twins" to adjoining settlements that are not "identical and like-minded beings with a strong feeling of belonging together" is mislabeling of "paired border towns" (Buursink, 2001, p. 7). Others assume that it is unnecessary to be at the high stage of identical integrity at the moment when cities name themselves twins (Joenniemi, 2014, Figenschou, 2011). The author admits that an essential criterion of considering a pair of border cities to be twins is their feeling of commonness and shared destiny in the past, present and future with a particular focus on coming years. Thus, in this article twinning is interpreted in a broad sense including statements of intentions to construct and maintain the common space or to reach common goals.

To study existing cross-border flows of goods and people, the author relied on the concept of the "bandwidth of familiarity" (Spierings and Van der Velde, 2007, p. 501) to understand which characteristics of border cities pull, push, keep or repel borderlanders to exercise cross-border mobility.

As Viken (2007) has shown using the Russian-Norwegian border as an example, the strong barrier function of the border could be also used as a source of touristic attractiveness for those travellers who are eager to face the strict but accessible border.

The Chinese side is already enjoying both incoming tourist flow of Russians and the inbound tourist flow from China that together resulted in substantial leap of the Chinese open border cities (namely Heihe, Manzhouli, Suifenhe and Tongjiang) both in size and prosperity. In virtue of this fact the strategy of Chinese border cities might not coincide with intentions of their Russian counterparts.

On the strength of the applicable nature of border tourism studies, the research question of this article is whether consensus and joining effort of two sides of the border is necessary to use "twin-cities" as a touristic brand.

\section{Methodology}

The paper relies on academic literature and research fieldwork in the selected cities. The fieldwork was aimed to explore two layers of perception of relations between Blagoveshchensk and Heihe - an expert perspective based on 
the interviews of people who are involved in carrying out cross-border activities within their professional duties and residents' opinion extracted from completed questionnaires.

The article is built on analysis of sixty questionnaires (fifty from Blagoveshchensk residents and ten from Heihe residents) and six interviews (three from Blagoveshchensk experts and three from Heihe experts). The objective shortcoming of the fieldwork is that it was completed with only Russian speaking respondents and lacks opinions of Heihe residents who don't speak Russian.

The analysed sections of the author questionnaire comprise of four units-1) awareness of the concept "Twin Cities"; 2) attitude towards the city on the other side of the border; 3) perception and evaluation of collaboration between cities and 4) expectations and proposals for cooperation between Blagoveshchensk and Heihe.

Due to low amount of collected questionnaires in Heihe, only qualitative analysis is applied to them in the paper. Questionnaires of Blagoveshchensk residents are interpreted both quantitatively and qualitatively.
Interviewees included state representatives (regional and municipal servants), experts working in the field of mass media and higher education. Five out of six interviewees for ethical reasons are cited anonymously.

Combining methods of induction and deduction in the research allowed the author first to narrow down the case study for an in depth analysis of the Russian-Chinese border tourism at the city level and second to put it in the context of (cross-border) region.

\section{General characteristic \\ of Russian-Chinese cross-border trade and tourism}

The Russian-Chinese land border is the second largest land border of the Russian Federation (after the Russian-Kazakh border) and is measured as 4209 kilometres in length with a relatively short western section and a quite vast eastern section of the border (see the map of the region in the Figure 1 and 2). Both North-East provinces of China and the Russian Far East has similar reputation within their countries as peripheral less developed and underpopulated

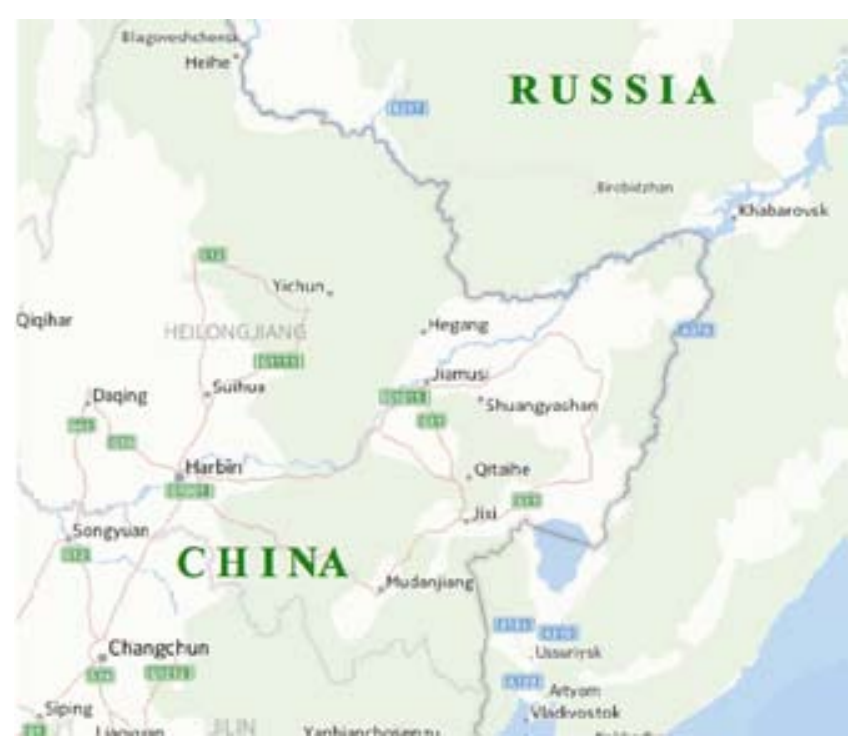

Fig. 1. Eastern section of the Russian-Chinese borderland. Source: http://www.flashearth.com/ 


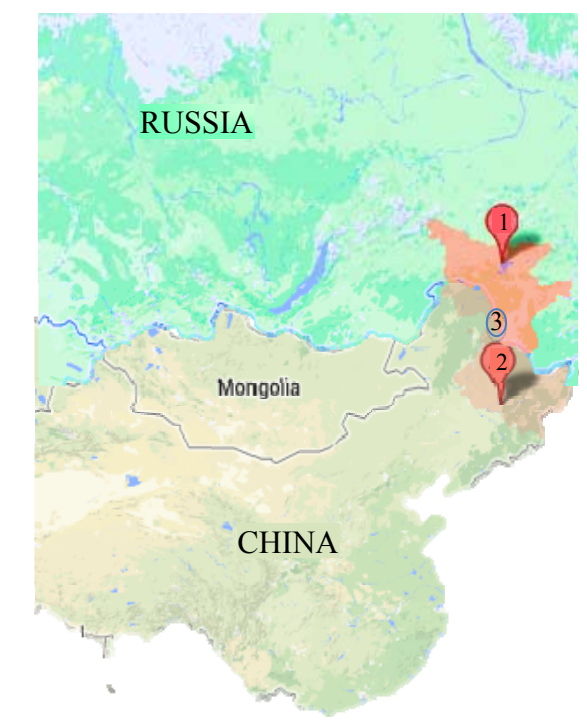

Fig. 2. Map of the Heilongjiang Province and the Amur Oblast. Explanation: 1 - Amur Oblast (Russia); 2 - Heilongjiang Province (China); 3 - City pair of Blagoveshchensk and Heihe. Source: Author

areas. At the same time since late 1980 s crossborder cooperation in various fields including tourism has gained closer attention in bilateral relations of the two states.

Open borders and price differentials in the neighbouring territories provide a constant temptation to seek personal gain (Prosvirnov, 2009, p. 66) which results in indivisible character of tourism and trade in many borderlands including one under scrutiny. Although the first tourist group exchange over the Russian-Chinese border was arranged in 1988 (Nechaeva, 2008, p. 227), more than for two decades it was hardly possible to draw the line between tourism and cross-border smallscale trade ${ }^{1}$.

There are several points of view on reasons for the emergence of the shuttle trade in the region. Some scholars tend to see deep historical roots of illegal economic practices that are common along the Sino-Russian border. For example, Zatsepine interprets "people trade" as an absence of respect to the borders inherited by new Russian settlers from indigenous people who lived on the banks of the Amur river, hunting and fishing regardless artificial boundaries wherever the nature allowed (2007, p. 159). The other version suggests the concrete organization of the border regime as a chief precondition of the "suitcase commerce" (Bruns, Miggelbrink and Muller, 2011, p. 668). The carried out fieldwork has shown that both explanations are corresponding with the reality. First, interviews collected in Blagoveshchensk proved that there is a clear presence of the nihilistic attitude among locals both to the border and related to it rules imposed by the authorities. Second, according to carried out survey of Blagoveshchensk residents, the customs on both sides of the border and the legal regulations were named as the main challenges for cooperation. The third most frequently adverted barrier to cooperation was the lack of infrastructure which coincides with obstacles to regional development in the NorthEast Asia previously mentioned by academics: for example, see three lacks - of confidence, of infrastructure and of investment capital proposed by Kim (2000, p. 54) and the forth 
lack - of sufficient peoplepower on both sides of the border - suggested by Zatsepine (2007, p. 159).

Small-scale trade is not the only informal economic activity performed in the borderland in question: prevalence of illicit cash movements (Novopashina, 2013, p. 47) and misuse of issued types of visas (Wishnick, 2000, p. 96) also are well-known features of the Sino-Russian borderlanders' life.

Perception of neighbours is ambiguous on both sides of the border. As the study of transborder interactions along the RussianChinese border made by Blyakher and Zelikova has demonstrated, Chinese people simultaneously appreciate economic benefits that are generated due to neighbouring Russia (as an easier access to Russian natural resources, trading Chinese goods on the Russian market, getting education in Russian universities or headhunting Russian specialists) and remember that Russians are relatively new to the North-East Asia and have conquered Chinese territories (2004, pp. 94-95).

As it was noticed during the fieldwork, the mindset of residents on the Russian side generally comprises of four camps:

1) admirers of China who tend to lead it as an example for modernization, economic power and hard work, these people try to surround themselves with everything Chinese and rejoice to spread the good image of China.

2) vigorous consumers that cross the border in search of better variety (and quality) of goods and services, this group consists of rational individuals hunting for the best deal with a clear economic motivation and careless holidaymakers with the focus on their leisure time experiences. The main difference within these sub-categories is the time of consuming: while rational individuals cross the border to meet the accumulated material needs and to stock up Chinese goods for later consumption at home, the holiday-makers are enjoying the time of visiting China without a particular wish to stuff the bag with Chinese goods.

3) anxious patriots who sound the alarm on necessity to withstand coming Chinese "silent expansion", consciously avoid using anything that is connected with China in their daily life and are proud of never crossing to China.

4) proponents of habitual proximity of China underlying the prosaism of the borderlanders' life and the commonness of sharing living space with several various Mongoloid ethnicities besides the Chinese as Buryats, Uyghurs and Yakuts.

While former two categories do not miss the chance to go to China, two latter are less willing (if not resisting) to cross the border. Certainly, to find the pure noted above attitudes is quite complicated - more likely, one person switches from one role to another depending on the geopolitical situation and prevailing personal life goals. At the same time, predisposition to one of these groups has implications both on potential of entering into partner relations with Chinese, personal behavior when in China and treatment of Chinese on the Russian side of the border.

\section{Adjacent settlements along Russian-Chinese border and their touristic potential}

There are several paired border settlements in the Russian-Chinese borderlands - all of them are located in relative proximity to each other and are separated with the state border. These border settlements vary significantly in their size, geographical distance between them and available means of crossing the border.

As Kim pointed out, population and economic activities in the Russian Far East gravitate towards the railway (2000, p. 44). 
Taking it as a basic assumption, the author has classified Russian cities located in relative proximity to the Sino-Russian state border into three categories: 1) age-old settlements that served as "major military posts and springboards to eastward expansion along the Amur river" (Zatsepine, 2007, p.157) - these cities mostly have grown in size and importance and became regional centers (for example, Khabarovsk and Blagoveshchensk); 2) settlements with railway stations of primary transit function founded to serve the needs of the Trans-Siberian railway (for instance, Zabaykalsk, Skovorodino, Belogorsk, Grodekovo, Khasan, etc.) and 3) settlements not connected with the railway - after opening of the border some of them became bridgeheads of border guard garrisons, others turned into portsof-entry from China to Russia (for example, Amurzet, Pashkovo, Turiy Rog, etc.). Among these three groups of towns only two former types have the potential of the tourism development due to combination of available resources and their (perspective) focus on contact function of the border. Settlements that are functioning as railway stations already serve as a conductor of flows of either cargo or passengers or both. The historical centres accumulate the historical and cultural heritage, they represent the islands of the Russian civilization in sparsely populated Far Eastern taiga.

As Wishnick has stated, the Russian Far East constitutes a "European foothold in the northeast Asia" (2000, p. 87). No wonder that pairs of Russian-Chinese border towns usually are referred to as "places of contrast" that pertain to "distinct cultural worlds" (Zatsepine, 2007, p.151). Such large dissimilarities in a relatively small area invite neighbours to come and have a look (Spierings and Van der Velde, 2008, p. 4) and increase the mutual touristic attractiveness of both sides of the border. On the other hand, as Gurova pointed out the differences should not be too strong in order not to repel the tourists (2012, p. 20).

The Russian-Chinese borderland reveals two opposite tendencies. First, there is an articulate willing of Chinese border provinces for more substantial integration with the Russian side. Treating the population of Russian settlements as the key target group of consumers, Chinese entrepreneurs have profoundly adjusted to tastes and needs of Russian clients. This trend could be seen in the ubiquity of Cyrillic signs all over the open border Chinese cities and abundance of initiatives for organizing better cross-border transportation - both in terms of working hours and capacity of processing the crossborder flows of people and goods. Second, while Chinese border towns are promptly evolving from small remote villages to centres of cross-border trade and tourism, their Russian counterparts mostly remain unchanged. Such a rising disproportion of development has caused enmity among many Russian borderlanders who have started to blame Chinese trading towns for "owing their prosperity to border trade and tourist flows from Russia”. However, these remarks are reasonable only to certain extent: besides active trading, Chinese border provinces for years have been enjoying special preferential regime provided for them by the Central Government of China. For instance, tax reductions, received subsidies and status of open border cities that are visa-free for Russian citizens. The later measure was introduced by the Chinese central government in 1994 and was upgraded in 2000 as an element of border development policy (Nechaeva, 2008, p. 2). Existing visa-free regime for Russian visitors solves the problem of waiting for issuing proper documents but it doesn't repeal the cost of border crossing. Despite paying for visa, travelers pay harbor and customs fees. 


\section{Blagoveshchensk and Heihe: \\ from contiguous settlement \\ to transborder agglomeration}

The city pair of Blagoveshchensk and Heihe stands out from the rest of Russian-Chinese adjoining settlements for the set of reasons. First, the combination of geographical proximity and the size of both cities is unique. In the contrast to considerable distances between the closest open border Chinese towns and Russian Far East urban centers, Blagoveshchensk and Heihe are divided only with 700 meters of the open water (for comparison the distance between Khabarovsk and Fuyuan is $65 \mathrm{~km}$, between Birobidzhan and Tongjiang - $155 \mathrm{~km}$ and between Vladivostok and Suifenkhe $-230 \mathrm{~km}$ ). Located in the upstream of the Amur River where it is not as wide as it becomes downstream gives the cities the advantage of the constant visual contact. Being of almost equal size (212 500 inhabitants in Blagoveshchensk (Government of Blagoveshchensk, 2008) and around 170000 inhabitants in Heihe (according to Chinese interviewee), the cities are regarded as the most populous border city pair in the RussianChinese borderlands.

Second, Blagoveshchensk is the administrative centre of the Amur Oblast which provides the city pair with additional administrative resources because decisions both at the municipal and regional level are made in the same place - within one district of the city what helps to ease and speed up the multi-layered process of international ties coordination on the Russian side of the border.

Third, the city pair under the scrutiny historically has accommodated several pilot projects of regional, national and macro-regional value. As Ivanov reported, since 90s Heilongjiang province authorities have used Heihe as a bargaining tool in the negotiations with Beijing to get and enlarge the tax reductions and funds for capital construction (2013, p.199). In 2002
Blagoveshchensk and Heihe were chosen as the testing area for using national currencies of both states in bilateral bank operations. Thanks to successful running of said experiment, the right to open accounts in yuan and rubles was granted first for all border regions along the RussianChinese border and later for some other Russian regions (Ryzhova, 2009a, p. 9).

Although by geographic position Blagoveshchensk and Heihe present a traditional example of twin-cities directly facing each other, there is no consensus about defining this city pair as twin-cities either among academics, politicians or residents of both places.

Excluding Blagoveshchensk and Heihe from the list of twin-cities usually is justified with a number of asymmetries existing between two cities. The most striking of them would be the disconnection of two settlements confronting their objective geographic proximity. During most time of the year Blagoveshchensk and Heihe do not have a permanent bridge connection. The main possible border crossing is a ferry. The pontoon bridge has been organized every winter after freezing-over of the Amur River for last three years (Spetstekhnika Kitaya, 2011). When it functions, border crossing is available both with a bus service and on the board of hovercrafts. Both ferries and buses are managed by the Russian company "AmurASSO". The monopolistic character of border crossing (both in terms of means of transport and the provider of the service) results in a relatively high price of going to China ${ }^{2}$. Economically speaking, such a poor system of transportation between Blagoveshchensk and Heihe prevents this border-crossing point from leading in terms of goods transported through customs among other Russian-Chinese bordercrossing points.

Second, those academics and journalists who are inclined that twin-cities should demonstrate certain level of similitude, underpin the outer 
contrast between the two cities. Wherein earlier it was more common to come across contrasting Europe and Asia using Blagoveshchensk and Heihe as an example, today the most noticeable and widely mentioned contradistinction is seen in modernity of Heihe and backwardness of Blagoveshchensk. The easiest unit of comparison is the waterfront of each city: for instance, see Kucera (2009) who described the Chinese side as a "glitzy, welcoming facade", while the Russian bank of the Amur river was depicted as "a barely lighted promenade" with "a Soviet-era World War II memorial that consists of a gunship with its barrels aimed across the river, toward China”.

More than that, Blagoveshchensk is the fifth biggest city in the Russian Far East with quite stable population size: the city has more than 200000 inhabitants from the end of 1980s. Heihe is a new centre of North-Eastern China and an administrative centre of the Heihe urban district, one of eleven urban districts in the Heilongjiang Province. During last 20 years Heihe is experiencing a remarkable step-up that resulted in tripling in size.

Due to a rapid increase of population Heihe is experiencing intense migration flows. According to Chinese interviewees, the main cause for incoming migration to Heihe is workrelated issues - people are arriving either because of the relocation of the organization they are working for (the relocation of the power plant of the city Bei'an to Heihe could be shown as an example) or due to their search for a better life. The last category of adventurers contains people both from other Northeastern and Southern provinces of China. Many of them don't succeed in adapting to the Northern weather and climate, give up seeking for their fortune and go back to their home places. Thus, almost everybody is relatively new in Heihe. Blagoveshchensk has a slight permanent growth of population but in general its residents are stable.
There is also a psychological issue on the frequency of exchanging visits between cities in question: as we can see from the survey, Russians go to Heihe to feel abroad, to change the scene, to consume goods and services of other origin, while according to collected interviews on the Chinese side, an average resident of North-East provinces of China doesn't go abroad frequently or even hasn't been abroad (for better understanding interviewees used an example, if a Chinese person has been abroad it is considered a great achievement and a fact to be proud of). If a Heihe resident doesn't have to cross the Russian-Chinese border because of work or studying on the Russian side, with high probability we can say that if he or she has resources to cross the border, he or she will visit Blagoveshchensk once while Blagoveshchensk residents in general go to Heihe on relatively regular basis treating this activity as a part of their annual life routine. According to conducted survey, only $6 \%$ of Russian borderlanders have never been to Heihe, while other $94 \%$ from time to time are visiting the other bank of the Amur River. The majority of those who go to Heihe, cross the Russian-Chinese border couple of times per year (60\%), another $30 \%$ go several times per month, $6 \%$ - several times per week and $4 \%$ couple of times per day.

Nevertheless, the term "twin-cities" is applied to describe cities on both sides of the border. According to available open sources covering development of the Russian-Chinese border (Consulate General of People's Republic of China in Khabarovsk, 2005) and the Chinese expert interviewees, 2005 was the year of appearance of the "twin-cities" concept on the agenda of the Heihe municipal government. That year was marked by the visit of Wang Zhigan, a prominent Chinese journalist to whom the authorship of idea to use the "twin-cities" for branding of Heihe is attributed. The concept got 


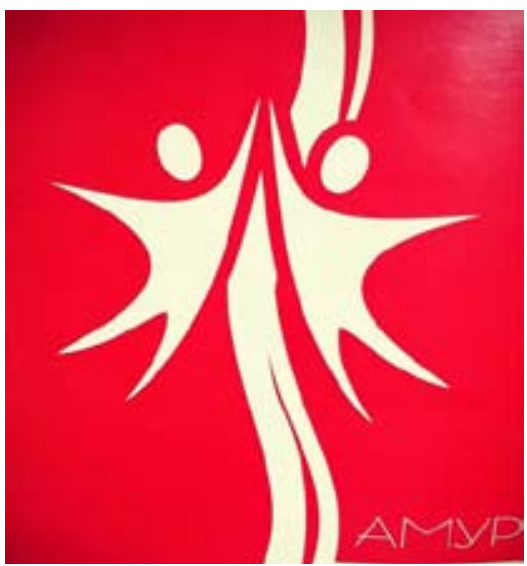

Fig. 3. Logo of Blagoveshchensk. Source: Ministry of Foreign Economic Relations, Tourism and Entrepreneurship of the Amur Oblast, 2013

a new slogan - "Two countries, one city" and mainly is expected to come true within economic and humanitarian cooperation. In 2006-2007 the idea of the twin-cities was proposed to the Russian side but it hasn't gained support in that time.

The Russian side did not agree to apply the term "twin-cities" to Blagoveshchensk and Heihe until 2011 when during the trilateral Russian-Chinese-Mongolian Tourism Forum in Manchuria the project of reconstructing the central embankment in Blagoveshchensk was presented. The idea is to reclaim 42.5 hectares of land currently being the Amur riverbed (Kuzmina, 2011). Now this project is known as the "Golden Mile" project and represents the core of the touristic strategy called "Twin Cities".

Today the "Golden Mile" project is one of the most significant investment projects of the Amur Oblast in the field of tourism, the main and the only official context of using the term "twincities" to Blagoveshchensk and Heihe on the Russian side. The project was presented to Russian Government in January 2013 (Interfax Russia, 2013) but still did not find federal approval.

Over time of its existence the project "Golden Mile" has attained quite big publicity on the regional level, especially within the latest campaign of touristic promotion of the Amur Oblast. One of campaign's outcomes was a new logo of Blagoveshchensk. It consists of two jumping schematically drawn persons giving "high five" over the river (see Fig. 3). Another deliverable was the touristic brochure that highlights regional places of interest. The first touristic attraction mentioned in it is the "unique transborder agglomeration of Blagoveshchensk and Heihe". The settlements are described as "two cities of one river that belong to two powerful states, two great world civilizations, two outstanding cultures" (Ministry of Foreign Economic Relations, Tourism and Entrepreneurship of the Amur oblast, 2013, p. 1) underlying simultaneous oneness and duality.

\section{Twin-cities as a touristic brand}

On Chinese side the term "twin-cities" has been widely used for the place promotion of Heihe within China since 2005 and could be assessed as a success story if we consider that in 2013 Heihe was visited by 4,5 million of Chinese tourists (Ganapolskiy, 2013).

Blagoveshchensk has more modest results: as the Minister of Foreign Economic Relations, 
Tourism and Business of the Amur Oblast Igor Gorevoy mentioned in the interview with the author, in 2012 the city had 38000 Chinese tourists which equals $15 \%$ of all Chinese tourists received in Russia in that year.

Chinese tourists have dominated the flow of international incoming tourists in Amur Oblast for a long time - since Blagoveshchensk has lost the status of the closed city. Till 2005 the main touristic attraction of the Amur Oblast's centre for Chinese was gambling. After the national ban to have slot machines the tourist flow from China has decreased by almost twice and reached the point of 10000 people per year. By 2010 the number of Chinese tourists came back to 20000 people. The cooperation programs are named as a crucial instrument for revitalizing the touristic flow from China to Russia (Government of the Amur oblast, 2012).

Although these numbers don't look convincing enough, the Amur Oblast administration treats tourism industry as the potential provider of sound income for regional and municipal budgets for the next 20-30 years. The argumentation for this is that tourism as an industry of producing impressions allows entering the huge Chinese market without competition because if a person wants to visit Russia - he or she should cross to Russia. While production of any goods is cheaper in China, no "Russian village" could be compared to experience of visiting Russia itself (interview with Igor Gorevoy).

Saying that, regional authorities of the Amur Oblast concede that to become an international travel destination, Blagoveshchensk lacks tourist attractions. To solve this problem the "Twin Cities" strategy purports to position Blagoveshchensk as a centre of Russian-Chinese congresses and expositions on trade and investment cooperation. Achieving this goal implies comprehensive construction activities that encompass building of a transborder cableway as a smooth, fast and comfortable means of border crossing, an Exhibition and Convention Centre, a Dinosaur Museum named "A Cretaceous Period Park", an Aerospace Museum called "A Space Odyssey", an Orthodox Cathedral, a Centre of Modern Art, a residential complex titled "Little Holland" reproducing the architectural appearance of the Netherlands in the $19^{\text {th }}$ century, an entertainment center called "Venice" with a possibility to take a real gondola, a hotel complex, a park, a pedestrian street for selling arts and crafts, an aqua park and a sport complex with an indoor skating rink (Government of the Amur oblast, 2013). As one can see, the list of intended construction work seems to be exorbitantly long and random. Along with the fact that by June 2013 only two of aforesaid building sites got private investors (a Russian investor was found for the cableway and a Chinese one for the "Venice" mall Ganapolskiy, 2013), it induces to diagnose the low degree of enforceability of the "Twin cities" strategy in the nearest future.

Another drawback of the project in question is that initially it was created for bringing prosperity only for the Russian side of the border. Furthermore, following the text of the "Twin cities" strategy, the project came to life as a reaction towards the booming inbound tourism development on Chinese side on the Amur River (Government of the Amur oblast, 2013). In other words, the idea of Amur Oblast regional strategy was to use the positive externalities of successful tourist promotion of Heihe in the internal tourism market of Mainland China.

Last but not least reason for doubts in prospects of tourism development in the Amur Oblast is the fact that the economic benefit from incoming Chinese tourists is minimal for Russian local travel agencies and regional economy as upon arrival a Chinese citizen usually prefers to receive services from local Chinese communities 
(Nechaeva, 2008, p. 230). This fact increases the risk of low returns of investments and might frighten away the potential contributors.

On the one hand, recent developments of reaching mutual understanding on both banks of the Amur River are positive: after two years of nearly zero reaction towards the Amur Oblast initiative, in March 2014 the Government of Heihe finally has stated its support for making a joint transborder tourism product under the umbrella of "Twin-Cities" with the aim to turn the adjacent settlements into a world-renowned travel destination. However, commenting the cooperation ahead, the Mayor of Heihe Zhang Enliang underlined that according to agreed action plan all construction work will be carried out on two sides of the border separately and linked between each other later (Chinese Internet Information Centre, 2014). Such a remark eliminates the vain dreams on extensive assistance of Chinese in building new tourist sites on the Russian side of the border.

While millions of incoming Chinese travelers are just a dream, the residents of Heihe might provide Russian tourist agencies with a feedback on visiting Blagoveshchensk. Surveyed Chinese respondents appreciate in Russian neighbouring city its cleanness, fresh air and politeness of its dwellers, the residents of Blagoveshchensk among considerable characteristics of Heihe named low prices of goods and wide variety of available services, different culture, good roads, everything in order and possibility to take inexpensive flights to other touristic destinations. The same consumerist motivation to cross the border was shown when Russian borderlanders were asked to name the aim of visiting Heihe: $74 \%$ of them claimed to come for touristic purposes and $46 \%$ for shopping (it was a multiple choice question where respondents were allowed to select several variants). Thereby, residents of Blagoveshchensk and Heihe demonstrate very dissimilar ways of "consuming the space" of the neighbour city in their prioritization of city's features.

\section{Conclusions}

The outbound Chinese tourists have considerably influenced the development of tourism industry both worldwide (Zhang, Pine and Zhang, 2000) and in the borderlands of countries neighbouring China (Xue and Gen, 2010). Despite of this global trend, the RussianChinese borderland so far hasn't experience mutual benefits from the flow of travellers. Exploring the extent to which border tourism is developed across the Russian-Chinese border, the author proves unbalanced one-sided structure of tourist flow with predominance of Russian tourists crossing the border to China.

On account of ambiguous attitudes of Russian Far East residents towards Chinese people, not a single initiative in the sector of hospitality treating Chinese travelers as a target group of visitors has been proposed. The ice was broken by the tourism development strategy of the Amur Oblast called "Twin Cities" that was put forward in 2011. Since presenting the aforementioned strategy, the term "twin cities" has started to be officially utilized to name a key perspective tourist attraction of the region - the contiguous settlements of Blagoveshchensk and Heihe.

Relying on the fieldwork in cities under scrutiny, the author admits a mismatch of the Russian-Chinese border city pair with the traditional European model of twining relations when two constant audiences are visiting each other from time to time and making stable contacts over the border. In addition to changeable population base on the Chinese bank of the Amur River, the relations of Blagoveshchensk and Heihe have a set of other asymmetries such as status inequality, character of urban development and the absence of the consensus on meaning 
of the term "twin-cities". These factors hamper the process of creation and maintenance of joint transborder touristic attractiveness of the adjacent settlements.

While the planned character of intercity cooperation makes the calendar of joint events stable and predictable, these events cannot be a basis of a tourism cluster. To form a new competitive tourism product, the immense construction work should be done. Taking into account the constant lack of investment capital in the North-East Asia, the author concluded that overcoming this ingrained regional challenge requires pooling the sources and efforts to lobby and promote the "Twin Cities" as a touristic brand.

Notwithstanding the length and inconsistency of presented list of investment projects to be done in Blagoveshchensk, the presence of strong support of regional authorities on the Russian side and recently voiced interest of the Chinese side gives a hope that the "Twin Cities" initiative might reshape the character of tourism in the Russian-Chinese borderlands from one-sided cross-border tourism and onesided border tourism concentrated in Heihe to reciprocal cross-border flows of visitors of both banks of the Amur River.

\footnotetext{
The phenomenon of small-scale cross-border trade in the context of the Russian-Chinese border got several names. In Chinese sources it is often referred to as "people trade" (Ryzhova, 2009b, p. 2) or "folk trade" (Prosvirnov, 2009, p.69). In Russian sources it is called "suitcase commerce" (ibid, p. 66) which is a literal translation of Russian "chemodannya torgovlya", although the most wide spread Russian term is "chelnochnaya torgovlya" (English "shuttle trade").

22200 rubles and $100 \mathrm{RMB}$ which in total is about 60 euro while the average per capita income in the Amur region in 2011 equaled 376 euro and subsistence minimum of 170 euro (Rosstat, 2011).

3 So called «Russian village» was built in a distance of $20 \mathrm{~km}$ from Heihe city centre as a venue for filming a movie «A zori zdes' tikhie» ["The Dawns Here Are Quiet"].
}

\section{References}

1. Anishchenko, A., \& Sergunin, A. (2012). Twin-cities: a new form of cross-border cooperation in the Baltic region? [Goroda-bliznetsy: novaya forma prigranichnogo sotrudnichestva $v$ Baltiiskom regione?] // Baltic region. Vol. 1 (11), pp. 27-38.

2. Blyakher, L., \& Zelikova, J. (2004). Cultural peculiarities of economic transborder interactions [Kulturnye osobennosti ekonomicheskogo transgranichnogo vzaimodeistviya] // Journal of sociology and social anthropology, Vol. 7, No.1. St. Petersburg, pp. 90-102.

3. Bruns, B., Miggelbrink, J., \& Muller, K. (2011). Smuggling and small-scale trade as part of informal economic practices: empirical findings from the Eastern external EU border // International Journal of Sociology and Social Policy, Vol. 31, No. 11/12, pp. 664-680.

4. Buursink, J. (2001). The binational reality of border-crossing cities // GeoJournal, Vol. 54. Netherlands, Kluwer Academics Publishers, pp. 7-19.

5. Chinese Internet Information Centre. (2014). The Mayor of Heihe: we will use all available resources to build the tourist attraction "Russian-Chinese twin-cities". [Mer Heihe: brosim vse sily na stroitel'stvo turisticheskogo ob" ekta "russko-kitaiskie goroda-bliznetsy"]. Available at: http://russian. dbw.cn/system/2014/03/07/000819004.shtml (accessed 3 April 2014).

6. Chinese Special Equipment [Spetstekhnika Kitaya]. (2011). Pontoon bridge between Blagoveshchensk and Heihe. [Pontonnyi most Blagoveshchensk-Heihe]. Available at: http://www.ctkamur.ru/news/pontonnyi-most-blagoveschensk-heihe/ (accessed: 22 March 2014).

7. Consulate General of People's Republic of China in Khabarovsk. (2005). Heihe and Blagoveshchensk are the first and so far the only "twin cities" on the Sino-Russian border. 
Available at: http://www.chinaconsulate.khb.ru/rus/xwdt/t200696.htm (accessed: 20 December 2013).

8. Gelbman, A. (2010). Border tourism attractions as a space for presenting and symbolizing peace. In: Eds. Moufakkir O. and Kelly I. Tourism, progress and peace, 83-98, Wallingford: CABI.

9. Joenniemi, P. (2014). City-twinning as Local Foreign Policy: The Case of Kirkenes-Nickel. CEURUS EU-Russia paper, N.15. Available at: http://ceurus.ut.ee/wp-content/uploads/2011/06/EURussian-paper-15_Joenniemi.pdf (accessed: 15 March 2014).

10. Interfax Russia. 2013. International agglomeration of Blagoveshchensk and Heihe was presented to Shuvalov during his visit to the Amur Oblast. [Shuvalovu v Priamur'e predstavili proekty po razvitiu mezhdunarodnoi aglomeratsii "Blagoveshchensk-Heihe”] Available at: http://www. interfax-russia.ru/FarEast/news.asp?id=376517\&sec=1671 (accessed: 9 February 2014).

11. Ioffe, G., \& Ryzhova, N. (2009). Trans-Border Exchange between Russia and China: the Case of Blagoveshchensk and Heihe // Eurasian Geography and Economics, Vol. 50, No. 3, pp. 348-364. Available at: http://gioffe.asp.radford.edu/images/pubpdfs/transborder.pdf (accessed: 28 February 2014).

12. Ivanov, S. (2013). Economic and symbolic capital at the border of globalizing China: the case of Heilongjiang province. In: Borders and Transborder processes in Eurasia. Eds. Sevastianov S., Richardson P. and Kireev, A. Vladivistok, Dalnauka Publishing House, pp. 188-203. Available at: http://www.dvfu.ru/documents/5766181/6851582/Borders\%20and\%20Transborder\%20Processes\%20 in\%20Eurasia (accessed: 15 March 2014).

13. Figenschou, A. (2011). The Twin Cities of Petchenga Rayon and Sør-Varanger Municipality. Master Thesis. The Faculty of Humanities. University of Oslo. 106 p.

14. Ganapolskiy, M. (2013). Interview with the Minister of Foreign Economic Relations, Tourism and Business of the Amur Oblast Igor Gorevoy. Radio "Echo Moscow" in Blagoveshchensk. Available at: http://www.echo.msk.ru/programs/beseda/1093928-echo/ (accessed: 2 April 2014).

15. Government of Blagoveshchensk. (2008). Conception of developing Blagoveshchensk till 2020 adopted under the order No. 2164 of the Blagoveshchensk's mayor. [Kontseptsiia razvitiia goroda Blagoveshchenska do 2020 goda, utverzhdennaia postanovleniem mera Blagoveshchenska No. 2164].

16. Government of the Amur Oblast. (2011). The bill No. 616 of the Amur Oblast Government "On adopting the long-term program "Development of tourism and ethnocultural heritage of the Amur Oblast for 2012-2016". [Postanovlenie Pravitel'stva Amurskoi oblasti ot 23.09.2011 N 616 "Ob utverzhdenii dolgosrochnoi tselevoi programmy Razvitie turizma i etnokul'turnogo naslediia v Amurskoi oblasti na 2012-2016 gody”]. Available at: http://www.amurobl.ru/wps/portal/!ut/p/c5/04_SB8K8xLLM9MSSzPy8xBz9CP0os3gTAwN_ RydDRwN_S1dDA0_f4GALIwP3ICNLY30v_aj0nPwkoEo_j_zcVP2C7EBFALU8x1Q!/d13/d3/ L2dJQSEvUUt3QS9ZQnZ3LzZfNDAwT0FCMUEwT0Y4MDBJVUFKOVJIN0xQSjM!/ (accessed: 1 March 2014).

17. Government of the Amur oblast. (2012). The bill No. 380 of the Amur Oblast Government "On adopting the Strategy of socio-economic development till 2025". [Postanovlenie Pravitel'stva Amurskoi oblasti ot 13.07.2012 No. 380 "Ob utverzhdenii Strategii sozial'no-ekonomicheskogo razvitiia Amurskoi oblasti na period do 2025 goda”]. Available at: http://www.amurobl.ru/wps/

$$
-449-
$$


portal/!ut/p/c4/04_SB8K8xLLM9MSSzPy8xBz9CP0os3gTAwN_RydDRwMLi0AzA09L5yALZ0 IMsQY_2CbEdFAFEGI94!/ (accessed: 22 March 2014).

18. Government of the Amur oblast. (2013). Strategy of developing Blagoveshchensk as a centre of international Russian-Chinese exhibitions and congresses - the investment project "Golden Mile". [Kontseptsiia razvitiia goroda Blagoveshchenska kak mezhdunarodnogo rossiiskokitaiskogo tsentra kongressno-vystavochnoi deiatel'nosti - investitzionnyi proekt "Zolotaia milia”].

19. Guo, Y., Kim, S. \& Timothy, D. J. (2007). Development Characteristics and Implications of Mainland Chinese Outbound Tourism // Asia Pacific Journal of Tourism Research. Vol. 12, No. 4, pp. 313-332.

20. Gurova, O. (2012). Why do St. Petersburg residents go shopping to Finland? Research of transborder shopping. [Pochemu peterburzhtsy otpravliaiutsa za pokupkami v Finliandiiu? Issledovanie transgranichnogo shopinga]. Economic Sociology, Vol. 13, No.1, pp. 18-37. Available at: http://ecsoc. hse.ru/data/2012/06/29/1255784835/ecsoc_t13_n1.pdf (accessed: 26 February 2014).

21. Kim, W. B. (2000). Designing a cooperative economic region through mega-projects in Northeast Asia. 37-57. Paper presented at the 17th EAROPH World Congress "Local Development and Planning in the $21^{\text {st }}$ century”, Asan city, Korea. Available at: http://www.earoph.info/pdf/2000papers/15. pdf (accessed: 23 March 2014).

22. Kucera, J. (2009). Where Russia meets China: Don't Call Them Twin-Cities. Available at: http://www.slate.com/articles/news_and_politics/dispatches/features/2009/where_russia_meets_ china/dont_call_them_twin_cities.html (accessed: 1 April 2014).

23. Kuzmina, E. (2011). Blagoveshchensk and Heihe have been to Manchuria. [Blagoveshchensk i Heihe pobyvali v Man'chzhurii]. Amurskaya Pravda, No. 92 (27155). Available at: http://www. ampravda.ru/2011/05/26/030351.html (accessed: 22 October 2013).

24. Ministry of Foreign Economic Relations, Tourism and Entrepreneurship of the Amur Oblast. (2013). Amur: Choose your map! [Amur: Vyberi svoyu kartu!]. 12 p.

25. Nechaeva, A. (2008). The main stages of Chinese outbound tourism development to Russia. [Etapy razvitiia kitaiskogo vyezdnogo turizma v Rossiiu]. Tourism and Regional Development, pp. 227233. Available at: www.dvfu.ru/meteo/geogr/recreation/docs/13.doc (accessed: 3 March 2014).

26. Novopashina, A. (2013). The effect of the border on Chinese direct investments: evidence from Russian border regions. Eurasia Border Review, Vol. 4, No. 2, pp. 37-55.

27. Prosvirnov, S. (2009). Migration between the Amur Region and China at the turn of the $21^{\text {st }}$ century. Far East Affairs, Vol. 37, No. 2, pp. 62-72.

28. Ryzhova, N. (2009a). Peculiarities of transmigrant adaptation in the "twin-cities" of Blagoveshchensk and Heihe. Blagoveshchensk, Amur State University. Available at: http://www.inocenter.ru/news/doc/natalia_ryzhova.pdf (accessed: 13 January 2014).

29. Ryzhova, N. (2009b). Role of cross-border cooperation in development of border cities of China and Russia. [Rol' prigranichnogo sotrudnichestva $v$ razvitii okrainnykh gorodov Kitaia $i$ Rossii]. Problems of the Far East. Available at: http://www.northasianborders.net/wp-content/uploads/ RizhovaFarEastProblem-copyl.pdf (accessed: 9 January 2014).

30. Spierings, B. \& van der Velde, M. (2007). Cross-border Shopping and the "Bandwith of Familiarity". Exploring the Positive Impact of National Borders on Consumer Mobility in the Euregion 
Rhine-Waal. Working paper series 2007/04. Available at: http://repository.ubn.ru.n1/handle/2066/69012 (accessed: 22 March 2014).

31. Spierings,B.\&vanderVelde,M.(2008). Shopping,BordersandUnfamiliarity:ConsumerMobility in Europe. Tijdschrift voor Economische en Sociale Geografie. Vol. 99, No. 4, pp. 497-505. Available at: http://econpapers.repec.org/ article/blatvecsg/v_3a99_3ay_3a2008_3ai_3a4_3ap_3a497-505.htm (accessed: 4 February 2014).

32. Viken, A. (2007). Celebrating the Cold War: Tourism related to the Norwegian-Russian boundary. Paper presented at thel6th Nordic Tourism Research Symposium. Helsingborg, Sweden.

33. Wishnick, E. (2000). Russia in Asia and Asians in Russia. SAIS Review, Vol. 20, No.1, pp. $87-100$.

34. Xue, J. \& Gen, N. (2010). Relation of inbound tourism flow from neighboring countries into the border provinces in Manland China. Tourism Tribune, Vol. 4.

35. Zatsepine, V. (2007). The Amur: as river, as border. In: Chinese State at the Borders. UBC Press, pp. 151-161.

36. Zhang, G., Pine, R. \& Zhang, H. Q. (2000). China's international tourism development: present and future. International Journal of Contemporary Hospitality Management, Vol. 12, No. 5, pp. 282290.

\section{Приграничный туризм}

\section{в российско-китайском порубежье}

\section{Е.В. Михайлова}

Высшая школа экономики

Россия, 101000, Москва, ул. Мясницкая, 20

Статья анализирует попытку создания дальневосточными регионами России индустрии гостеприимства, ориентированной на китайских потребителей. На примере стратегии развития туризма Амурской области «Города-близнецыь» автор оценивает возможность корректировки существующей несбалансированной односторонней структуры туристических потоков в российско-китайском приграничье. Определив отличительные черты взаимоотношений Благовещенска и Хэйхэ, автор делает вывод об уникальности этой пары городов среди других смежных поселений, разделенных российско-китайской границей. Учитывая практическую направленность применения термина «города-близнецьл» $\kappa$ изучаемым городам, автор предполагает, что подобная риторика является элементом повышения их туристической привлекательности и конструирования туристического бренда.

Ключевые слова: приграничный туризм, трансграничная агломерация, города-близнецы, приграничные города, российско-китайское приграничье.

Научная специальность: 08.00.00 - экономические науки. 